LANA LUČIĆ*

lana.lucic@pilar.hr

ANDREJA BRAJŠA-ŽGANEC*

andreja.brajsa.zganec@pilar.hr

LJILJANA KALITERNA LIPOVČAN*

ljiljana.kaliterna@pilar.hr

TIHANA BRKLJAČIĆ*

tihana.brkljacic@pilar.hr

INES SUČIĆ*

ines.sucic@pilar.hr

*Institut društvenih znanosti Ivo Pilar
Primljeno: 09. 10. 2019.

Prihvaćeno: 16. 10. 2019

DOI: $10.21857 / y 54 j o f p 51 m$

\title{
ODNOS RODITELJSTVA S INDIKATORIMA DOBROBITI
}

Roditeljstvo je direktno i indirektno povezano s dobrobiti pojedinca. Istraživanjem u sklopu CRO-WELL projekta pokazalo se kako roditelji u odnosu na osobe bez djece iskazuju veću opću dobrobit, ali manje zadovoljstva u pojedinim životnim domenama - postignućem, zajedništvom sa zajednicom, slobodnim vremenom i fizičkim izgledom. Spol i dob sudionika ostvaruje značajni interakcijski efekt $s$ roditeljstvom na zadovoljstvo pojedinim životnim domenama. Općem zadovoljstvu životom kod osoba s i bez djece značajno i u podjednakom udjelu pridonosi zadovoljstvo pojedinim životnim domenama, a značajno mu u oba poduzorka pridonose veće zadovoljstvo životnim standardom, postignućem, sigurnošću i ljubavnim životom. 


\section{UVOD}

Tijekom života pojedinac obnaša mnoge uloge, a roditeljska je jedna od važnijih (Gutmann, 1975). Još je Erikson (1963) naglasio centralnu ulogu roditeljstva u generativnosti i psihološkom razvoju, a najčešće je laičko vjerovanje potkrijepljeno rezultatima istraživanja kako roditeljstvo pridonosi psihološkom rastu pojedinca i osjećaju zadovoljstva, sreće i svrhovitosti života (Nelson i sur., 2013).

Roditeljstvo i danas ima vrlo salijentnu društvenu ulogu i često se u teorijama svrstava visoko među životne prioritete (Hansen, Slagsvold i Moum, 2009). Većina mlađih odraslih osoba planira roditeljstvo i smatra ga važnim životnim ciljem (Stanley, Edwards i Hatch, 2003; Toulemon, 1996), a Schoen i suradnici (1997) smatraju kako roditeljstvom zadovoljavamo osnovne psihološke potrebe poput one za afilijacijom, poštovanjem, sigurnošću, samo-ostvarenjem i pozitivnom slikom o sebi, te zadovoljenje tih potreba značajno determinira vlastitu dobrobit (npr. Lyubomirsky i Boehm, 2010; Ryan i Deci, 2001). Roditeljstvo se u teorijama promatra i kao ostvarenje važnog, pozitivno vrednovanog i društveno propagiranog životnog cilja te se interpretira kao osobni uspjeh koji rezultira osjećajem ponosa, samopouzdanja i zadovoljstva čime značajno pridonosi sreći pojedinca (npr. Michalos, 1985). Evolucijski psiholozi također postavljaju roditeljstvo na sam vrh piramide ljudskih potreba (Kenrick i sur., 2010) smatrajući kako roditeljstvo rezultira osjećajem smislenosti, zahvalnosti i nagrađenosti (White i Dolan, 2009; Schaie i Willis, 1996).

U prijašnjim se istraživanjima „ne imanje“ djece često povezivalo s negativnim emocijama npr. usamljenošću i ispraznošću i na neki se način osobe bez djece stigmatiziralo (vidi Hansen, 2012). Međutim nalazi dijela istraživanja ne potvrđuju kako roditelji vode sretnije i ispunjenije živote u odnosu na osobe bez djece, već da imaju manje slobodnog vremena, a više stresa, obaveza, briga i financijskih problema (Mirowsky i Ross, 2003). Rezultati govore u prilog i tomu kako su roditelji, u odnosu na osobe bez djece, ponekad više depresivni i anksiozni (npr. Clark, 2006; Evenson i Simon, 2005; Alesina i sur., 2004; Di Tella i sur., 2003), manje zadovoljni i doživljavaju više pozitivnih i negativnih emocija (Stanca, 2012), odnosno da su osobe bez djece sretnije i zadovoljnije životom od onih koji su roditelji (npr. Margolis i Myrskylä, 2011; Stanca, 2009; Ball i Chernova, 2008; Haller i Hadler, 2006). S obzirom na to da roditeljstvo često rezultira transformacijom životnih prioriteta koja zahtjeva značajnu reorganizaciju dotadašnjeg života (Nomaguchi i Milkie, 2003), takva promjena, iako pruža brojna zadovoljstva, odražava se na druge aspekte i životne uloge i direktno i indirektno utječe na dobrobit pojedinca. Primjerice, s roditeljstvom povezan manjak sna 
(Avison i sur., 2007), porast obaveza zbog skrbi za dijete (Kravdal, 1996; Rexroat i Shehan, 1987) i manjak slobodnog vremena (Buddelmeyer i sur., 2015) ili povećana financijska davanja (Nelson i sur., 2013; Stanca, 2009) značajno mogu pridonijeti smanjenju dobrobiti roditelja.

Nekonzistentnost u općim nalazima o pozitivnoj povezanosti roditeljstva i dobrobiti ipak nije iznenađujuća s obzirom na razlike među istraživanjima u npr. operacionalizaciji dobrobiti i korištenim mjerama dobrobiti, radi li se o kros-sekcijskim ili longitudinalnim istraživanjima, te koje su osobine sudionika (npr. dob, spol, osobine ličnosti, socio-ekonomski status) i djece (npr. broj djece, redoslijed rođenja, spol) razmatrane $u$ istraživanjima (npr. Margolis i Myrskylä, 2015; Kohler i sur., 2005).

Dok se u dijelu istraživanja dobrobit definira kao odsutnost negativnih i/ili prisutnost pozitivnih emocionalnih stanja, u drugima se uzima samo jedna globalna procjena dobrobiti (Marks i sur., 2004). lako opće mjere zadovoljstva životom ili razine sreće (mjerene jednom česticom) uglavnom umjereno koreliraju s drugim skalama dobrobiti (Sandvik, Diener i Siedlitz, 1993), njihova pouzdanost, kao i informativnost je manja. Također rezultati prethodnih istraživanja o kompleksnosti odnosa roditeljske i ostalih životnih uloga ukazuju na nužnost razmatranja povezanosti roditeljstva i zadovoljstva u pojedinim životnim domenama.

Rezultati istraživanja općenito govore u prilog tome kako povezanost roditeljstva i zadovoljstva životom varira s dobi roditelja (odnosno dobi djece) i spolom roditelja. Dok Margolis i Myrskylä (2011) i Nelson i sur. (2013) nalaze manje zadovoljstvo i sreću kod mlađih roditelja nego kod osoba iste dobi bez djece, dio istraživanja govori kako roditeljstvo djeluje pozitivnije na zadovoljstvo životom kod očeva (Nomaguchi i Milkie, 2003; Stanca, 2009; Nelson i sur., 2013), a dio na zadovoljstvo životom kod majki (Kohler i sur., 2005; Baranowska i Matysiak, 2011). U nekim istraživanjima je dobiveno kako očevi procjenjuju višom dobrobit na svim indikatorima nego muškarci bez djece, kao i to da su majke u odnosu na žene bez djece iskazivale manje negativnih i više pozitivnih emocija (Nelson i sur., 2013) te više razine zadovoljstva životom i više samopouzdanja (Hansen, Slagsvold i Moum, 2009). U kulturama u kojima je briga za dijete i dalje primarno majčina odgovornost, istraživanja su pokazala kako majke u odnosu na očeve doživljavaju više stresa, brige i uznemirenosti (npr. Savolainen i sur., 2001; Bird i Roger, 1998; Mirowsky i Ross, 2003) i potencijalno jači sukob između poslovne i obiteljske domene što može imati negativne posljedice po njihovo zadovoljstvo (npr. Gatrell i sur., 2013). Roditeljstvo, pogotovo kad su djeca mlađe dobi i kad je skrb za njih intenzivna može značajno negativno doprinositi zadovoljstvu životom roditelja uslijed povećanih ekonomskih izdavanja i stvaranja sukoba u dvije 
važne domene posao-obitelj, ali prema teoriji zahtjeva -nagrada (engl. demandreward) psihološke nagrade roditeljstva (npr. samo-pouzdanje, samo-efikasnost, roditeljsko zadovoljstvo), koje su najveće kod roditelja djece mlađe od 5 godina (Nomaguchi, 2012), često premašuju njegove ekonomske troškove.

Istraživanja o povezanosti roditeljstva i dobrobiti u srednjoj i starijoj dobi ne dovode do jednoznačnih rezultata. Dio istraživača ne nalazi pozitivnu povezanost zadovoljstva i roditeljstva u 40-im (npr. Margolis i Myrskylä, 2011), dok drugi pronalaze da su roditelji mlađe i srednje dobi (26-62 god.) (npr. Nelson i sur., 2013), odnosno roditelji do 45 godina starosti (npr. Herbst i Ifcher, 2012) sretniji od osoba iste dobi bez djece. Herbst i Ifcher (2012) bilježe kako sreća roditelja s porastom dobi i dalje relativno raste $u$ odnosu na osobe bez djece, Margolis i Myrskylä (2011) isto izvještavaju o pozitivnoj povezanosti zadovoljstva i roditeljstva nakon 50-e godine i to značajno više kod žena nego li kod muškaraca, dok Nelson i sur. (2013) nisu kod starijih osoba (stariji od 63) uočili razlike u zadovoljstvu s obzirom na roditeljstvo. Hipoteze i nalazi istraživanja o tome kako roditeljstvo nema dugoročan učinak na zadovoljstvo životom (Myrskyla i Margolis, 2014; Frijters i sur, 2011; Clark i sur., 2008) i da nije povezano sa zadovoljstvom životom kod sudionika srednje i starije dobi (Bergman i Daukantaite, 2006; Kohler i sur., 2005; Savolainen i sur., 2001) ili da je ta povezanost vrlo slaba no pozitivna (Daukantaite i Zukauskiene, 2006; Dykstra i Wagner, 2007) sukladne su teoriji polazne točke dobrobiti (set-point theory). Pretpostavlja se da relativno brzo nakon rođenja djeteta dolazi do adaptacije na taj životni događaj i da se naše zadovoljstvo životom, s ciljem ostvarenja vlastitog psihološkog balansa, vraća na razinu prije rođenja djeteta (npr. Mikucka, 2016; Myrskyla i Margolis, 2014). Međutim, prema afektivnim teorijama smatra se kako dobrobit ovisi o ispunjenju ljudskih potreba (npr. fiziološke potrebe, sigurnost, poštovanje, ljubav) (Veehoven, 2009) te da će zato životni događaji imati dugotrajne učinke na dobrobit, pogotovo oni iz najvažnijih životnih domena - obitelji i zdravlja (Easterlin, 2005). Nalaz da roditeljstvo više pridonosi dobrobiti i sreći kod starijih nego mlađih roditelja (Hilleras i sur., 2001; Mikucka, 2016) tumači se i time da roditeljstvo predstavlja dugoročni „ulog“ u dobrobit roditelja (npr. McLanahan i Adam, 1987). I iz perspektive Eriksonove teorije (1963) ljudi se u srednjoj životnoj dobi (40 do 60 godine starosti) suočavaju s dilemom generativnosti (stvaranja) nasuprot stagnacije. Ostvarenjem generativnosti, koja uključuje i roditeljstvo, pojedinac ostvaruje osobni razvoj kroz vrlinu brige, odnosno kroz skrb za svoju djecu, vlastiti posao i dobrobit drugih, dok u suprotnom dolazi do stagnacije tj. nema osobnog razvoja. S obzirom na pretpostavljenu povezanost ostvarene generativnosti i dobrobiti, roditeljstvo će u toj životnoj dobi rezultirati s više dobrobiti. 
Kompleksnosti razmatranja veze roditeljstva i dobrobiti dodatno pridonose nalazi koji govore kako su medijatori i/ili moderatori povezanosti roditeljstva i dobrobiti, osim dobi i spola roditelja i prilike u ostalim domenama života kao što su npr. obrazovanje, zaposlenje, socio-ekonomski status, odnos s partnerom i sl. Općenito se pokazalo kako lošiji životni uvjeti pridonose povećanoj razini roditeljskog stresa (Cunningham i Knoester, 2007; Crouter i Booth, 2004), pri čemu se taj doprinos pokazao značajnijim kad su djeca mlađe dobi.

Vodeći se nekonzistentnošću nalaza prijašnjih istraživanja ovim se istraživanjem željelo ispitati razlike između osoba s i osoba bez djece, uzimajući u obzir njihovu dob i spol: (1) u općim indikatorima dobrobiti - zadovoljstvo životom, sreća, prisutnost pozitivnih i negativnih emocija, te procvat; (2) u specifičnim indikatorima dobrobiti - zadovoljstvu s dvanaest domena života. Također se želio ispitati i doprinos socio-demografskih karakteristika sudionika i zadovoljstva pojedinim domenama života objašnjenju općeg zadovoljstva životom kod osoba s i bez djece.

\section{METODOLOGIJA ISTRAŽIVANJA}

\section{Sudionici}

Istraživanje je provedeno na prigodnom uzorku punoljetnih osoba, u sklopu Hrvatskog longitudinalnog istraživanja dobrobiti (CRO-WELL) koje je financirala Hrvatska zaklada za znanost (IP-2014-09-4398). U prvom valu je u istraživanju sudjelovalo 5177 sudionika, a za potrebe ovog rada korišteni su rezultati prikupljeni na 2752 sudionika koji su sudjelovali u drugom valu istraživanja. lako je u odnosu na prvi val došlo do osipanja $47 \%$ sudionika, struktura sudionika je u oba vala bila slična (vidi Lučić, Brkljačić, Kaliterna Lipovčan, 2018) te su i u drugom valu istraživanja u uzorku većinom sudjelovale mlađe i obrazovanije ženske osobe.

S obzirom na ciljeve istraživanja, ukupni uzorak je podijeljen na dva poduzorka: osobe s djecom ( $\mathrm{N}=1294)$ i osobe bez djece ( $\mathrm{N}=1458)$. Obrazovanje, radni status te mjesečni prihodi bili su u CRO-WELL istraživanju operacionalizirani kroz veći broj kategorija, međutim zbog raspodjele odgovora sudionika po pojedinim kategorijama te u svrhu pojednostavljenja prikaza karakteristika uzorka i dijela rezultata za potrebe ovog istraživanja svedeni su na dihotomne varijable ${ }^{1}$ (Tablica 1).

1 Raspodjela kategorija odgovora u dihotomne varijable objašnjena je u opisu korištenih instrumenata. 
Tablica 1: Socio-demografske karakteristike sudionika (frekvencije)

\begin{tabular}{|c|c|c|c|c|}
\hline \multicolumn{2}{|c|}{ Socio-demografske karakteristike } & $\begin{array}{l}\text { osobe s } \\
\text { djecom }\end{array}$ & $\begin{array}{l}\text { osobe bez } \\
\text { djece }\end{array}$ & ukupno \\
\hline \multicolumn{2}{|l|}{$\mathrm{N}$} & 1294 & 1458 & 2752 \\
\hline \multicolumn{2}{|l|}{$\operatorname{spol}\left(f_{\text {sudionice }}\right)$} & 1011 & 1163 & 2174 \\
\hline \multirow{2}{*}{ dob } & 18 - 39 godina & 400 & 1213 & 1613 \\
\hline & $\geq 40$ godina & 894 & 245 & 1139 \\
\hline \multicolumn{2}{|c|}{ u braku /vezi ( $f_{\text {odgovoriDA }}$ ) } & 1118 & 860 & 1978 \\
\hline \multirow{2}{*}{ obrazovanje } & $\leq$ srednja škola & 453 & 486 & 939 \\
\hline & > srednja škola & 831 & 955 & 1786 \\
\hline \multirow{2}{*}{$\begin{array}{l}\text { mjesečni prihodi po } \\
\text { članu obitelji }\end{array}$} & $\leq 4000 \mathrm{KN}$ & 681 & 565 & 1246 \\
\hline & $>4000 \mathrm{KN}$ & 525 & 768 & 1293 \\
\hline \multicolumn{2}{|l|}{ zaposleni $\left(f_{\text {odgovoriDA }}\right)$} & 1003 & 919 & 1922 \\
\hline
\end{tabular}

Poduzorak osoba s djecom bio je statistički značajno stariji $((t(1,2750)=38,01$, $p=0,00)$, više ih je bilo u vezi/ braku $\left(\left(\chi^{2}(1,2752)=254,87, p=0,00\right)\right.$, više ih je bilo zaposlenih $\left(\chi^{2}(1,2752)=59,05, p=0,00\right)$ te su imali niža mjesečna primanja po članu kućanstva $\left(\left(\chi^{2}(1,2752)=50,24, p=0,00\right)\right.$ u odnosu na poduzorak osoba bez djece. Poduzorak osoba s djecom se od poduzorka osoba bez djece nije statistički značajno razlikovao u razini obrazovanja $\left(\chi^{2}(1,2752)=0,73, p=0,40\right)$ i udjelu sudionica $\left(\chi^{2}(1,2752)=1,11, p=0,30\right)$.

\section{Postupak}

Istraživanje u sklopu CRO-WELL projekta je provedeno longitudinalno, primjenom online ankete u kojoj je korištena sveobuhvatna baterija upitnika (vidi Lučić, Brkljačić i Kaliterna Lipovčan, 2018), a koje su sudionici ispunjavali u tri vala $^{2}$, u razmaku od po godinu dana. Sadržaj baterije upitnika djelomično je variran u svakom valu sukladno ciljevima projekta. U istraživanju su mogle sudjelovati sve punoljetne osobe, a sudjelovanje je bilo dobrovoljno i sudionici su prije ispunjavanja ankete bili informirani o svrsi i načinu provođenja istraživanja. Kako bi se omogućilo longitudinalno prikupljanje podataka, sudionici su bili zamoljeni upisati svoju e-mail adresu prilikom prvog pristupa anketi. Nakon toga je za svakog sudionika tj. upisanu e-mail adresu, automatski generiran jedinstveni niz

2 Prikupljanje podataka u sklopu trećeg vala traje do kraja 2019. godine. 
znakova (token). Uparivanjem e-mail adresa i slučajno generiranih tokena bio je zaštićen identitet sudionika koji je bio nepoznat istraživačima, ali je administratoru ankete omogućio daljnje kontaktiranje sudionika u svrhu ponovljenih mjerenja. Sudionici su u svakom trenutku mogli odustati od sudjelovanja u istraživanju i zatražiti brisanje svojih podataka bez ikakvih negativnih posljedica. Provedbu istraživanja odobrio je etički odbor Instituta društvenih znanosti Ivo Pilar.

\section{Instrumenti}

Za potrebe ovoga istraživanja analizirani su rezultati sudionika prikupljeni u drugom valu istraživanja:

1. Zadovoljstvo životom kao pokazatelj kognitivne komponente dobrobiti ispitano je jednom česticom (vidi World Values Survey, 2007), na kojoj sudionici, na skali Likertova tipa od 11 stupnjeva (od 0 do 10), procjenjuju zadovoljstvo svojim životom. Pri tome viši rezultat upućuje na veće zadovoljstvo životom.

2. Sreća kao procjena afektivne komponente dobrobiti ispitana je također jednom česticom. Sudionici su na skali Likertova tipa od 11 stupnjeva (od 0 do 10), procjenjivali svoju sreću pri čemu je viši rezultati upućivao na višu razinu sreće. Pearsonova korelacija između skale zadovoljstva životom i skale sreće u drugom valu istraživanja je iznosila $r(2752)=0,83, p=0,00$.

3. Zadovoljstvo pojedinim domenama života ispitano je modificiranom skalom osobnog indeksa blagostanja (Personal Well-being Index, PWI, Cummins, 1996). Originalna PWI skala se sastoji od sedam čestica kojima se mjeri zadovoljstvo specifičnim aspektima života (standardom življenja, zdravljem, postignućem, odnosima, sigurnošću, pripadnošću zajednici, sigurnošću u budućnost) na skali Likertova tipa od 11 stupnjeva (od 0 do 10). Za potrebe CRO-WELL projekta, zadovoljstvo odnosima bilo je operacionalizirano s dvije čestice - zadovoljstvo odnosima s obitelji i zadovoljstvo odnosima s prijateljima, a ispitano je zadovoljstvo i s četiri dodatna aspekta: slobodnim vremenom, poslom, fizičkim izgledom i ljubavnim životom. Prijašnja istraživanja su pokazala kako PWI skala ima zadovoljavajuće metrijske karakteristike (Ganglmair-Wooliscroft i Lawson, 2008) te jednofaktorsku strukturu. $U$ drugom valu istraživanja, Cronbach $\alpha$ adaptirane verzije zadovoljstva pojedinim domenama života bio je 0,89.

4. Skala procvata (Flourishing Scale, Diener i sur., 2010) je subjektivna mjera uspješnosti pojedinca u važnim životnim područjima poput odnosa, samopouzdanja, optimizma i svrhe života. Skala se sastoji od osam čestica, a sudionici su slaganje sa svakom procjenjivali na skali Likertova tipa od 7 stupnjeva (od 1 uopće se ne slažem, do 7 - u potpunosti se slažem). Ukupni rezultat na skali se 
formira kao linearna kombinacija odgovora sudionika, s teoretskim rasponom od 7 do 56. Cronbach $\alpha$ skale procvata u drugom valu istraživanja iznosio je 0,9. Korelacija između skale procvata i skale zadovoljstva životom, kao i skale procvata i skale sreće u drugom valu istraživanja bile su identične i iznosile $r(2752)=0,68$, $p=0,00$.

5. Skala pozitivnih i negativnih emocije (The Scale of Positive and Negative Experience, SPANE; Diener i sur., 2010) sadrži 12 čestica pri čemu se 6 odnosi na pozitivne emocije (npr. osjećaj zadovoljstva), a 6 na negativne (npr. osjećaj tuge). Sudionik, uzimajući u obzir prethodni mjesec, svako iskustvo procjenjuje na skali Likertova tipa od 7 stupnjeva (od 1 - nikad, do 7 - gotovo uvijek). Teoretski raspon za pozitivne, odnosno negativne emocije je 7-42. Na podacima drugog vala istraživanja potvrđena je dvofaktorska struktura skale (vidi Lučić, Brkljačić i Kaliterna Lipovčan, 2018), a Cronbach $\alpha$ iznosio je 0,94 za skalu pozitivnih i 0,88 za skalu negativnih emocija.

Prikupljene su i informacije o socio-demografskim karakteristikama sudionika (spol, dob, stupanj obrazovanja, radni status, mjesečni prihod po članu kućanstva, jesu li u braku/vezi) te ima li osoba djece ili nema. Bračni status bio je operacionaliziran putem kategorije (u vezi/braku sam, nisam u vezi/braku). Šest kategorija kojima je bilo operacionalizirano obrazovanje, raspodijeljeno je dihotomizacijom na: niže obrazovanje (bez škole, završena osnovna ili srednja škola) i više obrazovanje (završena viša škola, dodiplomski studij, diplomski studij, i/ ili specijalistički/poslijediplomski studij). Devet kategorija kojima je bio operacionaliziran radni status raspodijeljeno je dihotomizacijom na: zaposlene osobe (stalno zaposleni u privatnom ili javnom sektoru, privremeno zaposleni, samozaposleni, poljoprivrednici) i nezaposlene osobe (nezaposleni, studenti, kućanice, umirovljenici). Mjesečni prihod po članu kućanstva bio je operacionaliziran u jedanaest kategorija (od 1- bez prihoda, do 11 - više od 15.000,00kn), a raspodijeljen je dihotomizacijom na: niže prihode (do 4000 kuna) i više prihode (više od 4000 kuna).

\section{Obrada rezultata}

Glavni učinak roditeljstva te interakcijski učinak dobi sudionika i roditeljstva, odnosno spola sudionika i roditeljstva na indikatore opće dobrobiti (zadovoljstvo životom, sreća, doživljene pozitivne i negativne emocije, procvat) i indikatore zadovoljstva pojedinim domenama života testirani su putem dvije multivarijatne analize varijance. Doprinos socio-demografskih karakteristika sudionika i zadovoljstva pojedinim domenama života objašnjenju općeg zadovoljstva životom 
kod osoba s djecom i osobama bez djece ispitan je hijerarhijskim regresijskim analizama. Sve analize provedene su u statističkom programu za analizu podataka SPSS v.24.

\section{REZULTATI}

Razlike u indikatorima opće dobrobiti i zadovoljstvu pojedinim domenama života

Sudionici s djecom i sudionici bez djece doživljavaju sreću i zadovoljstvo životom i pojedinim domenama života relativno visokim, odnosno iznad teorijskih prosjeka skala (Tablica 2). Također obje skupine sudionika relativno visokim doživljavaju procvat i relativno često doživljavaju pozitivne emocije, a relativno rijetko negativne emocije. Obje skupine sudionika najviše su zadovoljne s obitelji, prijateljima i zdravljem, a najmanje poslom, životnim standardnom i sigurnošću u budućnost. Međutim, i zadovoljstvo s domenama na kojima su sudionici iskazali najniže procjene više od teorijskih prosjeka skale.

Tablica 2: Rezultati osoba s i bez djece na indikatorima opće i specifične dobrobiti

\begin{tabular}{|c|c|c|c|}
\hline \multirow{3}{*}{\multicolumn{2}{|c|}{ Indikator dobrobiti }} & \multicolumn{2}{|c|}{ osobe } \\
\hline & & \multirow{2}{*}{$\begin{array}{c}\text { s djecom } \\
\mathrm{M}(\mathrm{SD})\end{array}$} & \multirow{2}{*}{$\begin{array}{c}\text { bez djece } \\
\mathrm{M}(\mathrm{SD})\end{array}$} \\
\hline & & & \\
\hline \multirow{5}{*}{ : } & zadovoljstvo životom & $7,02(2,13)$ & $7,00(2,01)$ \\
\hline & sreća & $6,92(2,22)$ & $6,82(2,11)$ \\
\hline & pozitivne emocije & $30,21(6,78)$ & $30,40(6,77)$ \\
\hline & negativne emocije & $18,81(6,54)$ & $19,95(6,45)$ \\
\hline & procvat & $45,15(7,51)$ & $44,66(7,82)$ \\
\hline \multirow{12}{*}{ 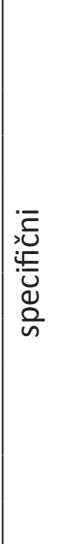 } & obitelj & $7,62(2,22)$ & $7,45(2,36)$ \\
\hline & prijatelji & $7,53(2,12)$ & $7,64(2,07)$ \\
\hline & zdravlje & $7,26(2,31)$ & $7,60(2,10)$ \\
\hline & ljubav & $6,77(3,01)$ & $6,34(3,36)$ \\
\hline & fizički izgled & $6,68(2,21)$ & $6,72(2,18)$ \\
\hline & postignuće & $6,67(2,32)$ & $6,75(2,27)$ \\
\hline & sigurnost & $6,61(2,65)$ & $7,05(2,50)$ \\
\hline & zajednica & $6,28(2,68)$ & $6,43(2,71)$ \\
\hline & slobodno vrijeme & $6,12(2,68)$ & $6,40(2,58)$ \\
\hline & posao & $6,00(2,93)$ & $5,88(2,91)$ \\
\hline & životni standard & $5,68(2,56)$ & $6,05(2,38)$ \\
\hline & sigurnost u budućnost & $5,28(2,77)$ & $5,45(2,75)$ \\
\hline
\end{tabular}


Prijašnja istraživanja (npr. Myrskyla i Margolis, 2014; Pollmann-Schult, 2014; Koropeckyj-Cox i Call, 2007; Bergman i Daukantaite, 2006; Evenson i Simon, 2005) su pokazala kako povezanost roditeljstva s dobrobiti varira ovisno o dobi i spolu te se činilo interesantnim, uz glavni učinak roditeljstva na opće indikatore dobrobiti i zadovoljstvo pojedinim domenama života, provesti i analize interakcijskog učinka dobi i spola s roditeljstvom. Međutim, s obzirom na to da je udio sudionika starije životne dobi $(\geq 60)$ bio mali $(5,1 \%)$, prilikom raspodjele sudionika na dobne skupine, a prema razvojnim periodima i Eriksonovoj psihosocijalnoj teoriji razvoja, jednu dobnu skupinu činile su osobe mlađe od 40 godina, dok su u drugu bile svrstane osobe srednje i starije dobi.

Tablica 3: Rezultati MANOVA - multivarijatni testovi

\begin{tabular}{|c|c|c|c|c|}
\hline \multirow{2}{*}{$\begin{array}{c}\text { Zavisne varijable } \\
\text { - indikatori } \\
\text { dobrobiti - }\end{array}$} & \multicolumn{4}{|c|}{ Nezavisne varijable $^{3}$} \\
\cline { 2 - 5 } & roditeljstvo & $\begin{array}{c}\text { roditeljstvo * } \\
\text { dob }\end{array}$ & $\begin{array}{c}\text { roditeljstvo * } \\
\text { spol }\end{array}$ & $\begin{array}{c}\text { roditeljstvo * } \\
\text { dob * spol }\end{array}$ \\
\hline \multirow{3}{*}{ opći $^{4}$} & $\mathrm{~F}^{5}=3,53$ & $\mathrm{~F}=0,72$ & $\mathrm{~F}=1,66$ & $\mathrm{~F}=0,28$ \\
& $\mathrm{p}=0,00$ & $\mathrm{p}=0,61$ & $\mathrm{p}=0,14$ & $\mathrm{p}=0,93$ \\
& $\eta^{2}=0,3 \%$ & $\eta^{2}=0,1 \%$ & $\eta^{2}=0,3 \%$ & $\eta^{2}=0,1 \%$ \\
\hline & & & & \\
& $\mathrm{F}=7,65$ & $\mathrm{~F}=2,84$ & $\mathrm{~F}=2,42$ & $\mathrm{~F}=1,58$ \\
& $\mathrm{p}=0,00$ & $\mathrm{p}=0,00$ & $\mathrm{p}=0,00$ & $\mathrm{p}=0,09$ \\
& $\eta^{2}=0,3 \%$ & $\eta^{2}=0,1 \%$ & $\eta^{2}=0,1 \%$ & $\eta^{2}=0,7 \%$ \\
\hline
\end{tabular}

Provedene su dvije MANOVE $2 \times 2 \times 2$ (roditeljstvo x spol x dob ${ }^{7}$ ), pri čemu su u prvoj MANOVI zavisne varijable bili opći indikatori dobrobiti, a u drugoj procjene zadovoljstva pojedinim domenama života (Tablica 3). Statistički značajnim se pokazao glavni učinak roditeljstva i na procjene opće dobrobiti

3 lako su se u MANOVI pokazali značajnim glavni efekti dobi (Pillai's Trace $=0,02, F(5,2740)=12.84$, $p=, 00$ ) i spola (Pillai's Trace $=0,03, F(5,2740)=14.12, p=0,00$ ) na opće indikatore dobrobiti i na specifične indikatore dobrobiti (dob - Pillai's Trace $=0,05, F(12,2733)=10,74, p=0,00$; spol - Pillai's Trace=0,03, $F(12,2733)=5,83, p=0,00)$ zbog zadanog opsega rada i postavljenih ciljeva oni nisu komentirani.

$4 d f(5,2740)$.

5 Zbog svoje robustnosti u slučajevima kada podaci ne zadovoljavaju u potpunosti zahtjeve MANOVE korišten je Pillai's Trace test čija vrijednost odgovara (vidi Tabachnick i Fidell, 2007).

$6 d f(12,2733)$.

7 Roditeljstvo $=$ da- ne, spol $=$ muški - ženski; dob $=$ mlađi od $40-$ stari 40 i više. 
$(F(5,2749)=3,53, p=0,00)$ i na procjene zadovoljstva pojedinim domenama života $(F(12,2733)=7,65, p=0,00)$, dok se interakcijski učinak roditeljstva i dobi sudionika $(F(12,2733)=2,84, p=0,00)$ te roditeljstva i spola sudionika $(F(12,2733)=$ $2,42, p=0,00$ ) pokazao značajnim samo na procjene zadovoljstva pojedinim domenama života, ali veličina tih učinaka je vrlo mala (vidi Cohen, 1988).

Rezultati MANOVE su pokazali kako postoji značajan glavni efekt roditeljstva na sve opće indikatore dobrobiti (Tablica 4a) i dio specifičnih indikatora dobrobiti - zadovoljstvo postignućem, zajedništvom sa zajednicom, slobodnim vremenom, fizičkim izgledom, obitelji, poslom i ljubavlju (Tablica 4b), a značajni interakcijski efekti roditeljstva i spola, te roditeljstva i dobi na dio specifičnih indikatora dobrobiti - zadovoljstvo pripadnošću zajednicom, slobodnim vremenom, prijateljima, fizičkim izgledom, ljubavnim životom (Tablica 4b). Unatoč zabilježenim značajnim efektima, njihova veličina je vrlo mala (Tablica 4a i Tablica 4b).

Tablica 4a: Rezultati MANOVA - testovi među skupinama za opće indikatore dobrobiti

\begin{tabular}{|c|c|c|c|c|}
\hline & \multirow{2}{*}{$\begin{array}{l}\text { Zavisne varijable } \\
\text {-indikatori dobrobiti- }\end{array}$} & \multicolumn{3}{|c|}{ Nezavisna varijabla - roditeljstvo } \\
\hline & & $F(1,2751)$ & $p$ & $\eta^{2}(\%)$ \\
\hline \multirow{5}{*}{ 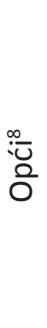 } & zadovoljstvo životom & 8,47 & 0,00 & 0,4 \\
\hline & sreća & 11,62 & 0,00 & 0,1 \\
\hline & procvat & 15,58 & 0,00 & 0,6 \\
\hline & pozitivne emocije & 7,12 & 0,01 & 0,3 \\
\hline & negativne emocije & 4,39 & 0,04 & 0,2 \\
\hline
\end{tabular}

$8 d f(5,2740)$. 
Tablica 4b: Rezultati MANOVA - testovi među skupinama za specifične indikatore dobrobiti

\begin{tabular}{|c|c|c|c|c|c|c|c|c|c|c|}
\hline \multirow{3}{*}{\multicolumn{2}{|c|}{$\begin{array}{c}\text { Zavisne varijable } \\
\text {-indikatori } \\
\text { dobrobiti- }\end{array}$}} & \multicolumn{9}{|c|}{ Nezavisne varijable } \\
\hline & & \multicolumn{3}{|c|}{ roditeljstvo } & \multicolumn{3}{|c|}{ roditeljstvo * dob } & \multicolumn{3}{|c|}{ roditeljstvo $*$ spol } \\
\hline & & $F(1,2757)$ & $\mathrm{p}$ & $\eta^{2}(\%)$ & $F(1,2757)$ & $\mathrm{p}$ & $\eta^{2}(\%)$ & $F(1,2757)$ & $\mathrm{p}$ & $\eta^{2}(\%)$ \\
\hline \multirow{12}{*}{ 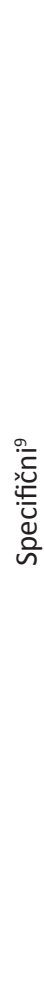 } & $\begin{array}{l}\text { životni } \\
\text { standard }\end{array}$ & 0,17 & 0,69 & 0,00 & 0,04 & 0,85 & 0,00 & 0,17 & 0,68 & 0,00 \\
\hline & zdravlje & 0,26 & 0,61 & 0,00 & 3,09 & 0,08 & 0,10 & 0,92 & 0,34 & 0,00 \\
\hline & postignuće & 6,59 & 0,01 & 0,20 & 3,56 & 0,06 & 0,10 & 2,32 & 0,13 & 0,10 \\
\hline & obitelj & 5,92 & 0,02 & 0,20 & 1,22 & 0,27 & 0,00 & 0,21 & 0,65 & 0,00 \\
\hline & prijatelji & 1,24 & 0,27 & 0,00 & 1,81 & 0,18 & 0,10 & 6,60 & 0,01 & 0,20 \\
\hline & sigurnost & 0,05 & 0,82 & 0,00 & 2,64 & 0,10 & 0,10 & 0,01 & 0,92 & 0,00 \\
\hline & zajednica & 6,65 & 0,01 & 0,20 & 6,84 & 0,01 & 0,20 & 4,24 & 0,04 & 0,20 \\
\hline & $\begin{array}{l}\text { sigurnost u } \\
\text { budućnost }\end{array}$ & 0,95 & 0,33 & 0,00 & 0,09 & 0,77 & 0,00 & 0,38 & 0,54 & 0,00 \\
\hline & $\begin{array}{l}\text { slobodno } \\
\text { vrijeme }\end{array}$ & 4,64 & 0,03 & 0,20 & 7,95 & 0,01 & 0,30 & 0,99 & 0,32 & 0,00 \\
\hline & posao & 5,92 & 0,02 & 0,20 & 1,02 & 0,31 & 0,00 & 3,60 & 0,06 & 0,10 \\
\hline & fizički izgled & 3,99 & 0,05 & 0,10 & 0,00 & 0,97 & 0,00 & 9,76 & 0,00 & 0,40 \\
\hline & ljubav & 46,48 & 0,00 & 0,17 & 0,27 & 0,61 & 0,00 & 4,87 & 0,03 & 0,20 \\
\hline
\end{tabular}

Naknadnim analizama glavnog efekta roditeljstva na opće indikatore dobrobiti utvrđeno je kako osobe s djecom pokazuju više zadovoljstva životom, više sreće i procvata, a manje pozitivnih i negativnih emocija u odnosu na osobe bez djece, dok je daljnja analiza značajnog glavnog efekta roditeljstva na specifične indikatore dobrobiti, pokazala kako osobe koje imaju djecu pokazuju manje

$9 d f(12,2733)$. 
zadovoljstva postignućem, zajedništvom sa zajednicom, slobodnim vremenom i fizičkim izgledom, a više zadovoljstva s obitelji, poslom i ljubavlju u odnosu na osobe koje nemaju djecu (vidi i Tablica 2). Naknadne analize značajnih interakcijskih efekata ${ }^{10}$ na specifične indikatore dobrobiti pokazale su kako:

(1) starije osobe bez djece osjećaju manje zadovoljstvo pripadnošću zajednici od mlađih osoba s i bez djece kao i od starijih roditelja. Mlađi roditelji zadovoljniji su pripadnošću zajednici od starijih roditelja.

(2) mlađi roditelji osjećaju manje zadovoljstvo slobodnim vremenom od starijih osoba s i bez djece i mlađih osoba bez djece.

(3) žene bez djece su zadovoljnije s prijateljima nego očevi i muškarci bez djece.

(4) muškarci bez djece manje su zadovoljni pripadnošću zajednici nego majke i žene bez djece.

(5) očevi su više zadovoljni fizičkim izgledom nego majke i žene i muškarci bez djece.

(6) muškarci bez djece su manje zadovoljni ljubavnim životom nego majke i očevi i žene bez djece.

\section{Predviđanje zadovoljstva životom na temelju zadovoljstva specifičnim životnim domenama kod osoba s i bez djece}

Kako bi se ispitalo pridonose li i u kojem stupnju karakteristike sudionika i zadovoljstvo pojedinim domenama života općem zadovoljstvu životom te jesu li doprinosi tih varijabli različiti ovisno o tome imaju li osobe djecu ili ne provedene su zasebne hijerarhijske regresijske analize na poduzorku osoba s djecom i poduzorku osoba bez djece (Tablica 5). U prvom koraku u hijerarhijsku regresiju su bile uvrštene socio-demografske karakteristike sudionika, a u drugom zadovoljstvo pojedinim domenama života.

10 Provedene su ANOVE uz Games-Howell post-hoc test, a uvid u rezultate dostupan je na zahtjev od autora koji zbog ograničenog opsega rada nisu prikazani u tekstu. 
Tablica 5: Doprinos socio-demografskih karakteristika sudionika i zadovoljstva pojedinim domenama života općem zadovoljstvu životom - rezultati hijerarhijske regresijske analize ${ }^{11}$

\begin{tabular}{|c|c|c|c|c|c|c|}
\hline \multirow{3}{*}{ Prediktori } & \multicolumn{6}{|c|}{ osobe } \\
\hline & \multicolumn{3}{|c|}{ s djecom } & \multicolumn{3}{|c|}{ bez djece } \\
\hline & B & $t$ & $p$ & b & $t$ & $p$ \\
\hline 1. korak & \multicolumn{3}{|c|}{$R^{2}=0,10, F(6,1158)=21,51, p=0,00$} & \multicolumn{3}{|c|}{$R^{2}=0,07, F(6,1247)=15,41, p=0,00$} \\
\hline \multicolumn{2}{|c|}{ (konstanta) } & 15,51 & 0,00 & & 16,79 & 0,00 \\
\hline Dob & $-0,03$ & $-1,02$ & 0,31 & $-0,19$ & $-6,32$ & 0,00 \\
\hline $\mathrm{Spol}^{11}$ & $-0,02$ & $-0,79$ & 0,43 & $-0,03$ & $-1,21$ & 0,23 \\
\hline Obrazovanje & 0,14 & 4,84 & 0,00 & 0,06 & 2,12 & 0,03 \\
\hline Zaposlenje & $-0,05$ & $-1,68$ & 0,09 & $-0,02$ & $-0,65$ & 0,52 \\
\hline Prihodi & 0,16 & 5,34 & 0,00 & 0,13 & 4,31 & 0,00 \\
\hline Brak/ veza & $-0,16$ & $-5,66$ & 0,00 & $-0,12$ & $-4,37$ & 0,00 \\
\hline 2. korak & \multicolumn{3}{|c|}{$\begin{array}{c}R^{2}=0,62, \Delta R^{2}=0,52, \\
\Delta F(12,1146)=132,02, p=0,00\end{array}$} & \multicolumn{3}{|c|}{$\begin{array}{c}R^{2}=0,61, \Delta R^{2}=0,54 \\
F(12,1235)=143,05, p=0,00\end{array}$} \\
\hline \multicolumn{2}{|c|}{ (konstanta) } & 4,56 & 0,00 & & 3,28 & 0,00 \\
\hline Dob & $-0,02$ & $-1,05$ & 0,30 & 0,01 & 0,29 & 0,78 \\
\hline Spol & 0,00 & $-0,10$ & 0,92 & 0,01 & 0,67 & 0,51 \\
\hline Obrazovanje & 0,03 & 1,57 & 0,12 & 0,00 & $-0,11$ & 0,91 \\
\hline Zaposlenje & 0,00 & 0,20 & 0,84 & $-0,04$ & $-1,79$ & 0,07 \\
\hline Prihodi & $-0,02$ & $-1,11$ & 0,27 & $-0,03$ & $-1,42$ & 0,16 \\
\hline Brak/ veza & 0,02 & 1,15 & 0,25 & 0,02 & 0,76 & 0,45 \\
\hline Životni standard & 0,21 & 7,86 & 0,00 & 0,24 & 9,93 & 0,00 \\
\hline Zdravlje & 0,00 & 0,15 & 0,88 & 0,03 & 1,29 & 0,20 \\
\hline Postignuće & 0,34 & 11,01 & 0,00 & 0,33 & 11,61 & 0,00 \\
\hline Obitelj & 0,03 & 1,15 & 0,25 & 0,02 & 0,72 & 0,48 \\
\hline Prijatelji & 0,04 & 1,33 & 0,19 & 0,04 & 1,54 & 0,12 \\
\hline Sigurnost & 0,12 & 3,88 & 0,00 & 0,06 & 2,21 & 0,03 \\
\hline
\end{tabular}

11 1= ženski, 2= muški. 


\begin{tabular}{|c|c|c|c|c|c|c|}
\hline \multirow{3}{*}{ Prediktori } & \multicolumn{6}{|c|}{ osobe } \\
\hline & \multicolumn{3}{|c|}{ s djecom } & \multicolumn{3}{|c|}{ bez djece } \\
\hline & B & $t$ & $p$ & b & $t$ & $p$ \\
\hline Zajednica & $-0,03$ & $-0,88$ & 0,38 & 0,10 & 3,85 & 0,00 \\
\hline $\begin{array}{ll}\text { Sigurnost } & \mathrm{u} \\
\text { budućnost } & \end{array}$ & 0,08 & 2,43 & 0,02 & 0,03 & 1,03 & 0,30 \\
\hline $\begin{array}{l}\text { S I o b o d n o } \\
\text { vrijeme }\end{array}$ & 0,01 & 0,22 & 0,83 & 0,04 & 1,73 & 0,08 \\
\hline Posao & 0,05 & 2,01 & 0,05 & 0,04 & 1,50 & 0,13 \\
\hline Fizički izgled & $-0,02$ & $-0,97$ & 0,33 & 0,04 & 1,58 & 0,12 \\
\hline Ljubav & 0,17 & 6,21 & 0,00 & 0,17 & 6,12 & 0,00 \\
\hline
\end{tabular}

Rezultati provedenih hijerarhijskih regresijskih analiza pokazali su značajan i sličan doprinos uvrštenih prediktora općem zadovoljstvu životom i kod osoba s djecom i kod osoba bez djece (Tablica 5). U prvom koraku regresijske analize doprinos socio-demografskih varijabli općem zadovoljstvu životom je kod oba poduzorka bio mali (10\%, odnosno $7 \%$ ) i u oba poduzorka značajno su zadovoljstvu životom pridonijeli više obrazovanje sudionika, veći mjesečni prihodi po članu kućanstva te ako su u braku/vezi. U poduzorku osoba bez djece u prvom koraku regresijske analize zadovoljstvu životom je značajno pridonijela i mlađa dob. $\mathrm{U}$ drugom koraku regresijske analize, zadovoljstvo pojedinim domenama života pridonijelo je objašnjenju dodatnih 52\%, odnosno 54\% varijance zadovoljstva životom, ovisno o poduzorku (Tablica 5). Doprinos socio-demografskih varijabli zadovoljstvu životom je nakon uvođenja zadovoljstva pojedinim domenama života postao neznačajan. Veće zadovoljstvo životnim standardom, postignućem, sigurnošću i ljubavnim životom značajno je pridonijelo predviđanju veće razine zadovoljstva životom u oba poduzorka. Kao značajni prediktori životnog zadovoljstva pokazali su se još i zadovoljstvo sigurnošću u budućnost i zadovoljstvo poslom u poduzorku osoba s djecom, a zadovoljstvo pripadnošću zajednici u poduzorku osoba bez djece (Tablica 5).

\section{RASPRAVA}

Rezultati ovog istraživanja koji pokazuju kako roditelji procjenjuju više zadovoljstva životom, više sreće i procvata i manje negativnih emocija od osoba bez djece sukladni su rezultatima istraživanja koji govore u prilog pozitivnim doprinosima roditeljstva na dobrobit (npr. Nelson i sur., 2013). Također, rezultati ovog 
istraživanja koji pokazuju kako su roditelji zadovoljniji s obitelji, poslom i ljubavnim životom od osoba koje nemaju djecu sukladni su nalazima kako roditeljstvo pozitivno djeluje na osjećaj povezanosti s prijateljima, obitelji i zajednicom (GaIlagher i Gerstel, 2001; Umberson i Gove, 1989) te da su roditelji više društveno integrirani tj. imaju veći broj kontakata s prijateljima i rodbinom u odnosu na osobe bez djece (Nomaguchi i Milkie, 2003), te da roditeljstvo i posredno preko ostvarene emocionalne veze s djetetom i/ili partnerom, može djelovati kao dodatni izvor socijalne integracije i emocionalne podrške (Umberson i Gove, 1989). Manje zadovoljstvo postignućem, slobodnim vremenom i fizičkim izgledom kod roditelja u odnosu na osobe bez djece direktno upućuje na domene života koje ponekad „trpe“ zbog roditeljstva. Tako su istraživanja pokazala da osobe bez djece imaju više slobodnog vremena, a manje obaveza, briga i financijskih problema (Mirowsky i Ross, 2003), te su manje izloženi sukobu poslovno-obiteljske domene (npr. Gatrell i sur., 2013) koja se onda može manifestirati u negativnoj procjeni zadovoljstva postignućima.

Na prvi pogled manje zadovoljstvo pripadnošću zajednici kod roditelja u odnosu na osobe koje nemaju djecu suprotan je prethodno navedenom pozitivnom učinku roditeljstva na društvenu integraciju. Međutim za potpunije razumijevanje odnosa roditeljstva i zadovoljstva sa specifičnim domenama života svakako je potrebno u razmatranje uzeti interakciju roditeljstva s dobi ${ }^{12}$ i spolom sudionika. Vezano uz zadovoljstvo pripadnošću zajednici interakcijski efekti su pokazali priličnu kompleksnost te je dobiveno kako je ono bilo manje kod starijih osobe bez djece nego kod mlađih i starijih roditelja i mlađih osoba bez djece, te da su mlađi roditelji zadovoljniji pripadnošću zajednici od starijih roditelja, a da su muškarci bez djece manje zadovoljni pripadnošću zajednici nego majke i žene bez djece. Temeljem dobivenog može se zaključiti kako roditeljstvo, pogotovo kod mlađih osoba, ipak djeluje kao zaštita od socijalnih i ekonomskih stresora potičući roditelje da održavaju važne društvene veze i povežu se sa zajednicom (npr. Herbst i Ifcher, 2012; Gallagher i Gerstel, 2001; Nomaguchi i Milkie, 2003), dok neimanje djece djeluje kao rizičan čimbenik za društvenu izolaciju kod starijih osoba bez djece, pogotovo muškaraca. Primjerice jedno od istraživanja na starijim osobama pokazalo je kako su oni koji su roditelji bili manje usamljeni (Wagner, Shutze i Lang, 1999). Utvrđeni interakcijski efekti upućuju i na to kako roditeljstvo, pogotovo kad su djeca mlađa i zahtijevaju intenzivniju skrb, može imati negativne učinke na druge domene života jer je dobiveno kako su mlađi

12 Obzirom da je dob roditelja i djece povezana, dob roditelja se može promatrati i kao indirektna mjera dobi djeteta/djece. 
roditelji manje zadovoljni slobodnim vremenom od osoba bez djece, a upravo se manjak slobodnog vremena često pokazuje kao jedna od prijetnji dobrobiti kod roditelja (Nelson i sur., 2013; Umberson i sur., 2010; Nomaguchi i Milkie, 2003).

U ovom su istraživanju žene bez djece iskazale veće zadovoljstvo prijateljima nego muškarci s i bez djece, a muškarci bez djece manje zadovoljstvo ljubavnim životom nego majke, očevi i žene bez djece. Može se pretpostaviti kako žene bez djece u odnosu na muškarce ulažu u i ostvaruju kvalitetnije prijateljske odnose, dok su muškarci bez djece u ovom uzroku bili oni koji su tijekom života ostvarili manje uspješne i/ili kvalitetne ljubavne odnose.

Očevi su iskazali više zadovoljstva fizičkim izgledom nego majke te žene i muškarci bez djece što je djelomično u skladu s rezultatima Loland (2000) koja na uzorku od 1555 osoba, različite dobi i različite razine fizičke aktivnosti, nalazi da su muškarci općenito zadovoljniji svojim fizičkim izgledom u odnosu na žene.

Od analiziranih socio-demografskih karakteristika i kod osoba s djecom i kod osoba bez djece većem zadovoljstvu životom pridonijeli su više obrazovanje sudionika, veći mjesečni prihodi po članu kućanstva te postojanje veze što je sukladno prijašnjim nalazima o općim čimbenicima koji pridonose zadovoljstvu životom (npr. Fernández-Ballesteros, Zamarrón Ruiz, 2001). Što se tiče roditelja, a vezano uz dobivene značajne prediktore zadovoljstva životom, prijašnja istraživanja su pokazala kako doživljavaju više stresa i depresivniji su samohrani roditelji (Helbig i sur., 2006; Evenson i Simon, 2005; Savolainen i sur., 2001; Aneshensel i sur., 1981) i oni nižeg obrazovanja i prihoda (O'Hara, 2009; Avison i Davies, 2005), da više obrazovanje korelira s većim porastom zadovoljstva životom tijekom roditeljske uloge, ali samo kod očeva (Myrskyla i Margolis, 2014), te da ekonomski resursi imaju zaštitnu ulogu od stresa prouzročenog roditeljstvom, pogotovo kod majki (Mikucka, 2016).

Međutim, potrebno je napomenut kako su analizirane socio-demografske karakteristike objasnile samo $7 \%$, odnosno $10 \%$ zadovoljstva životom te da je doprinosi socio-demografskih varijabli zadovoljstvu životom nakon uvođenja zadovoljstva pojedinim domenama života postao neznačajan. To nije iznenađujuće s obzirom na relativno visoku povezanost zadovoljstva pojedinim domenama života i ukupnog zadovoljstva životom. Veće zadovoljstvo životnim standardom, postignućem, sigurnošću i ljubavnim životom značajno je pridonijelo predviđanju veće razine zadovoljstva životom u oba poduzroka. Ovi rezultati su djelomično u skladu s nalazom da su zadovoljstvo postignućem, zdravljem, socijalnim vezama i standardom življenja najvažniji prediktor općeg zadovoljstva životom (e.g. Wills, 2009; Ganglmair-Wooliscroft i Lawson, 2008; Lau, Cummins i McPherson, 2005; Tiliouine, Cummins i Davern, 2006; Marinić i Brkljačić, 2008). U ovom istraživa- 
nju, zdravlje se nije pokazalo kao značajan prediktor zadovoljstva životom što može biti povezano i s time da je udio sudionika starijih od 60 godina u ovom istraživanju bio tek 5,1\%.

Kao značajni prediktori životnog zadovoljstva pokazali su se još i zadovoljstvo sigurnošću u budućnost i zadovoljstvo poslom u poduzorku roditelja, što nije iznenađujuće ako se uzme u obzir kako je roditeljstvo, pogotovo kad su djeca mlađe dobi i kad je skrb za njih intenzivna može značajno umanjiti zadovoljstvo životom roditelja uslijed povećanih ekonomskih izdavanja i (Nelson i sur. 2013) stvaranja sukoba između poslovne i obiteljske domene (npr. Gatrell i sur., 2013). Kao značajan prediktor životnog zadovoljstva u poduzoroku osoba bez djece pokazalo se zadovoljstvo pripadnošću zajednici te je moguće kako sudionici bez djece svoju potrebu za društvenom integracijom, koju roditelji djelomično ostvaraju preko djece, ispunjavaju putem ostvarivanja zajedništva unutar svoje društvene okoline.

Prilikom interpretacije rezultata svakako treba uzeti u obzir i ograničenja istraživanja, koja se primarno vežu uz karakteristike uzorka i dostupnosti mjera povezanih s karakteristikama roditelja i djece. Uzorak je prigodan što onemogućava donošenje općih zaključaka, a poznavanje nekih drugih karakteristika sudionika moglo je dodatno objasniti kompleksan odnos roditeljstva i dobrobiti. lako su analize pokazale značajni glavni učinak roditeljstva i značajne interakcijske efekta roditeljstva sa spolom i dobi na indikatore dobrobiti, veličine svih efekata su izrazito niske te da je značajnost dobivenih razlika vjerojatno i rezultat nekih drugih čimbenika (npr. određenog odstupanja rezultata od uvjeta za provedene statističke analize). Također potrebno je napomenuti i kako se rezultati vezani uz (ne)značajnost pojedinih prediktora zadovoljstvu životom svakako mogu objasniti i povezanošću procjena zadovoljstva među pojedinim životnim domenama (od $r_{\text {ljubav- posao }}=0,26$ do $r_{\text {sigurnost }- \text { zajednica }}=0,66, r_{\text {sigurnost }- \text { sigurnost u budućnost }}=0,73$ ) te veličinom i karakteristikama uzorka. S obzirom na to da se u sklopu CRO-WELL projekta radilo o sveobuhvatnom istraživanju dobrobiti, roditeljstvo je bila samo jedna od ispitanih varijabli te nisu bili zahvaćeni svi njeni aspekti, a među valovima istraživanja varirane su mjere vezane uz roditeljstvo. Primjerice, moguće je da bi se dobili drugačiji rezultati s obzirom na dobrobiti da je bilo moguće ispitati razlike među roditeljima koji su planirali roditeljstvo i onima kojima se ono neplanirano dogodilo, odnosno među osobama koje su svojevoljno odabrale život bez djece i kod kojih to nije bio rezultat svojevoljnog odabira (npr. Callan, 1987). Također dostupni podaci u drugom valu istraživanja nisu omogućili utvrđivanje dobi i spola djece i redoslijeda njihovog rođenja (Kohler i sur., 2005), jesu li osobe biološki roditelji ili npr. skrbnici, posvojitelji, niti razlikovanje roditelja koji žive 
sa svojom djecom od onih koji npr. zbog razvoda ili iseljenja odraslog djeteta ne žive s njima što se sve može odraziti na dobrobit (Herbst i Ifcher, 2016; Evenson i Simon, 2005). Također nije bilo moguće u punom opsegu obuhvatiti niti kompleksnost romantičnih odnosa npr. jesu li sudionici rastavljeni, udovci, je li im to prvi brak i sl., a istraživanja su pokazala kako je život bez djece povezan s depresijom i usamljenošću više kod udovaca i rastavljenih muškaraca (Zhang i Hayward, 2001). Dodatno, ovdje se radi i o kros-sekcijskom istraživanju, a Prema Herbst i Ifcher (2016) usporedbe među skupinama u trenutku istraživanja mogu dovesti do pogrešnih zaključaka. Naime, oni smatraju da osobe koje imaju, odnosno nemaju djecu mogu slijediti različite trendove dobrobiti pa se i moguća (izraženost) razlika među indikatorima mijenja (Herbst i Ifcher, 2016). U sljedećim istraživanjima svakako bi trebalo uključiti i neke od navedenih mjera, kao i mjere dobrobiti koje su osjetljive na kratkoročne i dugoročne učinke roditeljstva (Savolainen i sur., 2001), te po završetku CRO-WELL projekta provesti analizu longitudinalnih podataka kako bi se detaljnije ispitala povezanost roditeljstva i dobrobiti.

Doprinos ovog istraživanja jest provjera (ne)konzistentnosti postojećih nalaza o povezanosti roditeljstva i dobrobiti u dosadašnjim istraživanjima na hrvatskom uzorku, istovremeno ispitujući više indikatora dobrobiti te promatrajući interakciju roditeljstva s dobi i spolom sudionika. Nalazi se mogu upotrijebiti i u praktične svrhe, kao smjernice sustavu i nevladinim organizacijama kako podržati roditelje i one koji to nisu, u svim fazama njihovog života, npr. kroz povećanje osjećaja sigurnosti u budućnost za roditelje ili organizirane društvene aktivnosti za starije osobe koje nemaju djecu.

\section{ZAKLJUČAK}

Ovo istraživanje imalo je za cilj ispitati odnos roditeljstva s općim i specifičnim indikatorima dobrobiti. Rezultati su pokazali da su, u odnosu na osobe bez djece, roditelji zadovoljniji životom, sretniji, postižu više rezultate na skali procvata te doživljavaju manje negativnih emocija. Ujedno, oni su i zadovoljniji obitelji, poslom i ljubavnim životom. S druge strane, roditelji su manje zadovoljni postignućem, pripadnošću zajednici, slobodnim vremenom i fizičkim izgledom. Interakcijski efekti roditeljstva i spola te roditeljstva i dobi sudionika pokazali su se značajnim samo kod zadovoljstva specifičnim domenama života i to za zadovoljstvo pripadnošću zajednici, slobodnim vremenom, prijateljima, fizičkim izgledom i ljubavnim životom. Višim razinama zadovoljstva životom kod osoba s i osoba bez djece pridonose više razine zadovoljstva životnim standardom, postignućem, sigurnošću i ljubavnim životom. Kod roditelja, važnim prediktorom još 
su se pokazali i zadovoljstvo sigurnošću u budućnost i poslom, a kod osoba bez djece zadovoljstvo pripadnošću zajednici.

Napomena: Rezultati prikazani u ovom radu dio su projekta „Hrvatsko longitudinalno istraživanje dobrobiti“ CRO-WELL (IP-2014-09-4398) koje je financirala Hrvatska zaklada za znanost.

\section{LITERATURA}

1/ A. ALESINA, R. DI TELLA i R. MACCULLOCH, "Inequality and happiness: Are Europeans and Americans different?", Journal of Public Economics, 88, 2004., 2009-2042.

2/ C. S. ANESHENSEL, R.R. FRERICHS i V.A. CLARK, „Family roles and sex differences in depression", Journal of Health and Social Behavior, 22, 1981., 379393.

3/ W. AVISON, J. ALI, i D. WALTERS, "Family Structure, Stress, and Psychological Distress: A Demonstration of the Impact of Differential Exposure", Journal of Health and Social Behavior, 62, 2007., 911-26.

4/ W. R. AVISON i L. DAVIES, "Family Structure, Gender, and Health in the Context of the Life Course", The Journals of Gerontology Series B: Psychological Sciences and Social Sciences, 60(Special Issue 2), 2005., 113-116.

5/ R. BALL i K. CHERNOVA, "Absolute income, relative income, and happiness", Social Indicators Research, 88(3), 2008., 497-529.

6/ A. BARANOWSKA i A. MATYSIAK, "Does parenthood increase happiness? Evidence for Poland", Vienna Yearbook of Population Research, 9, 2011., 307-325.

7/ L. R. BERGMAN i D. DAUKANTAITE, "The importance of social circumstances for Swedish women's subjective wellbeing", International Journal of Social Welfare, 15(1), 2006., 27-36.

8/ C. BIRD i M. Roger, "Parenting and depression: The impact of the division of labor within coupes and perceptions of equity", PSTC Working Paper No. 98-09. Population Studies and Training Center. Providence, RI: Brown University, 1998.

9/ H. BUDDELMEYER, D.S. HAMERMESH i M. WOODEN, "The Stress Cost of Children", NBER Working Papers 21223, National Bureau of Economic Research, Inc., 2015., preuzeto 23.10.2019. s https://www.nber.org/papers/ w21223.pdf

10/ V. J. CALLAN, "The personal and marital adjustment of mothers and voluntarily and involuntarily childless wives", Journal of Marriage and the Family, 49, 1987., 847-856. 
11/ A. E. CLARK, "Born to be mild? Cohort effects don't explain why well-being is U-shaped in age", 2006, preuzeto 22.10.2019. s https://halshs.archivesouvertes.fr/halshs-00590307/document

12/ A.E. CLARK, E. DIENER, Y. GEORGELLIS i R.E. LUCAS, "Lags and Leads in Life Satisfaction: A Test of the Baseline Hypothesis", The Economic Journal, 118(529), 2008., 222-243.

13/ J. COHEN, Statistical power analysis for the behavioral sciences (2nd ed.), Hillsdale, NJ: Lawrence Erlbaum Associates, 1988.

14/ A. C. CROUTER i A. BOOTH, Work-family challenges for low-income parents and their children. Mahwah, NJ: Erlbaum, 2004.

15/ R. A. CUMMINS, "The domains of life satisfaction: an attempt to order chaos", Social Indicators Research, 38, 1996., 303-328.

16/ A. M. CUNNINGHAM i C. KNOESTER, "Marital status, gender, and parents' psychological well-being", Sociological Inquiry, 77(2), 2007., 264-287.

17/ D. DAUKANTAITE i R. ZUKAUSKIENE, "Swedish and Lithuanian employed women's subjective well-being", International Journal of Social Welfare, 15, 2006., 23-30.

18/ R. DI TELLA, R.J. MACCULLOCH i A.J. OSWALD, "The macroeconomics of happiness", Review of Economics and Statistics, 85(4), 2003., 809-827.

19/ E. DIENER, D. WIRTZ, W. TOV, C. KIM-PRIETO, D. W. CHOI, S. OISHI, i R. BISWAS-DIENER, "New well-being measures: Short scales to assess flourishing and positive and negative feelings", Social Indicators Research, 97(2), 2010., 143-156.

20/ P. A. DYKSTRA, i M. WAGNER, "Pathways to childlessness and late-life outcomes", Journal of Family Issues, 28(11), 2007., 1487-1517.

21/ R. EASTERLIN, "Building a better theory of well-being", U L. Bruni i P. Porta (ur.), Economics and happiness. Reality and paradoxes, Oxford: University Press, 2005., 29-64.

22/ E. H. ERIKSON, Childhood and Society: revised and enlarged, New York: W. W. Norton \& Company, 1963.

23/ R. J. EVENSON, i R.W. SIMON, "Clarifying the relationship between parenthood and depression", Journal of Health and Social Behavior, 46(4), 2005., 341-358.

24/ R. FERNÁNDEZ-BALLESTEROS, M.D. ZAMARRÓN i M. Á. RUIZ, “The contribution of socio-demographic and psychosocial factors to life satisfaction", Ageing \& Society, 21(1), 2001., 25-43.

25/ P. FRIJTERS, D.W. JOHNSTON i M.A. SHIELDS, "Life satisfaction dynamics with quarterly life event data", The Scandinavian Journal of Economics, 113(1), 2011., 190-211. 
26/ S. K. GALLAGHER i N. GERSTEL, "Connections and constraints: The effects of children on caregiving", Journal of Marriage and the Family, 63, 2001., 265275.

27/ A. GANGLMAIR-WOOLISCROFT, i R. LAWSON, "Applying the international wellbeing index to investigate subjective wellbeing of New Zealanders with European and with Maori heritage, Kotuitui: New Zealand", Journal of Social Sciences Online, 3(1), 2008., 57-72.

28/ C. J. GATRELL, S.B. BURNETT, C.L. COOPER i P. SPARROW, "Work-life balance and parenthood: A comparative review of definitions, equity and enrichment", International Journal of management reviews, 15(3), 2013., 300-316.

29/ D. L. GUTMANN, "Parenthood: Key to the comparative psychology of the life cycle?", U N. Datan i L. Ginsberg (ur.), Life-span developmental psychology: Normative life-crises. New York: Academic Press, 1975., 167-184.

30/ M. HALLER i M. HADLER, "How social relations and structures can produce happiness and unhappiness: An international comparative analysis", Social Indicators Research, 75(2), 2006., 169-216.

31/ T. HANSEN, "Parenthood and happiness: A review of folk theories versus empirical evidence", Social Indicators Research, 108(1), 2012., 29-64.

32/ T. HANSEN, B. SLAGSVOLD i T. Moum, "Childlessness and psychological wellbeing in midlife and old age: An examination of parental status effects across a range of outcomes", Social Indicators Research, 94, 2009., 343-362.

33/ S. HELBIG, T. LAMPERT, M. KLOSE i F. JACOBI, "Is parenthood associated with mental health? Findings from an epidemiological community survey", Social psychiatry and psychiatric epidemiology, 41(11), 2006., 889-896.

34/ C. M. HERBST i J. IFCHER, "A bundle of joy: does parenting really make us miserable?", 2012., preuzeto 25.10.2019. s https://journalistsresource.org/ wp-content/uploads/2011/08/parenting.pdf

35/ C. M. HERBST i J. IFCHER, "The increasing happiness of US parents", Review of Economics of the Household, 14(3), 2016., 529-551.

36/ P. HILLERAS, A.F. JORM, A. HERLITZ i B. WINBLAD, "Life satisfaction among the very old: A survey on a cognitively intact sample aged 90 years or above", International Journal of Aging and Human Development, 52(1), 2001., 71-90.

37/ D. T. KENRICK, V. GRISKEVICIUS, S. L. NEUBERG, i M. SCHALLER, "Renovating the pyramid of needs: Contemporary extensions built upon ancient foundations", Perspectives on Psychological Science, 5, 2010., 292-314.

38/ H. P. KOHLER, J.R. BEHRMAN i A. SKYTTHE, "Partner + children = happiness? The effects of partnerships and fertility on well-being", Population and Development Review, 31(3), 2005., 407-445. 
39/ T. KOROPECKY-COX i V.R. CALL, "Characteristics of Older Childless Persons and Parents Cross-National Comparisons", Journal of Family Issues, 28, 2007., 1362-1414.

40/ $\varnothing$. KRAVDAL, "How the Local Supply of Day-Care Centers Influences Fertility in Norway: A Parity-Specific Approach", Pop Research and Policy Review, 15, 1996., 201-218.

41/ A. L. LAU, R.A. CUMMINS, i W. MCPHERSON, "An investigation into the cross cultural equivalence of the Personal Wellbeing Index", Social Indicator Research, 72(3), 2005., 403-430.

42/ N.W. LOLAND, "The aging body: Attitudes toward bodily appearance among physically active and inactive women and men of different ages", Journal of Aging and Physical Activity, 8(3), 2000., 197-213.

43/ L. LUČIĆ, T. BRKLJAČIĆ, i LJ. KALITERNA LIPOVČAN, "Longitudinal online survey in well-being research: first experiences from CRO-WELL project", Iliria International Review, 8(1), 2018., 205-227.

44/ S. LYUBOMIRSKY i J.K. BOEHM, "Human motives, happiness, and the puzzle of parenthood: Commentary on Kenrick et al.(2010)", Perspectives on Psychological Science, 5(3), 2010., 327-334.

45/ R. MARGOLIS i M. MYRSKYLÄ, "A global perspective on happiness and fertility", Population and development review, 37(1), 2011., 29-56.

46/ R. MARGOLIS i M. MYRSKYLÄ, "Parental well-being surrounding first birth as a determinant of further parity progression", Demography, 52(4), 2015., 1147-1166.

47/ M. MARINIĆ, i T. BRKLJAČIĆ, "Love over gold - the correlation of happiness level with some life satisfaction factors between persons with and without physical disability", Journal of Developmental and Physical Disabilities, 20, 2008., 527-540.

48/ N. F. MARKS, L. BUMPASS i H.J. JUN, "Family roles and well-being during the middle life course", U O. G. Brim, C. D. Ryff i R. Kessler (ur.), How healthy are we? A national study of well-being at midlife, Chicago: University of Chicago Press, 2004., 514-549.

49/ S. MCLANAHAN, i J. ADAMS, "Parenthood and psychological well-being", Annual Review of Sociology, 13, 1987., 237-257.

50/ A. C. MICHALOS, "Multiple discrepancies theory (MDT)", Social Indicators Research, 16, 1985., 347-413.

51/ M. MIKUCKA, "How does parenthood affect life satisfaction in Russia?", Advances in Life Course Research, 30, 2016., 16-29.

52/ J. MIROWSKY i C.E. ROSS, Social causes of psychological distress (2nd ed.), New York: Aldine de Gruyter, 2003. 
53/ M. MYRSKYLÄ i R. MARGOLIS, "Happiness: Before and after the kids", Demography, 51(5), 2014., 1843-1866.

54/ S. K. NELSON, K. KUSHLEV, T. ENGLISH, E.W. DUNN i S. LYUBOMIRSKY, "In defense of parenthood: Children are associated with more joy than misery", Psychological Science, 24(1), 2013., 3-10.

55/ K. M. NOMAGUCHI, "Parenthood and Psychological well-being: clarifying the role of child age and parent-child relationship quality", Social Science Research, 41, 2012., 489-498.

56/ K. M. NOMAGUCHI, i M.A. MILKIE, "Costs and rewards of children: The effects of becoming a parent on adults' lives", Journal of Marriage and Family, 65(2), 2003., 356-374.

57/ M.W. O'HARA, "Postpartum Depression: What we Know", Journal of Clinical Psychology, 65(12), 2009., 1258-1269.

58/ M. POLLMANN-SCHULT, “Parenthood and life satisfaction: Why don't children make people happy?", Journal of Marriage and Family, 76, 2014., 319-336.

59/ C. REXROAT, i C. SHEHAN, "The family life cycle and spouses' time in housework", Journal of Marriage and the Family, 49, 1987., 737-750.

60/ R. M. RYAN i E.L. DECl, "On happiness and human potentials: A review of research on hedonic and eudaimonic well-being", Annual Review of Psychology, 52, 2001., 141-166.

61/ E. SANDVIK, E. DIENER i L. SIEDLITZ, "Subjective well-being: The convergence and stability of self-report and non-self-report measures", Journal of Personality, 61, 1993., 317-342.

62/ J. SAVOLAINEN, E. LAHELMA, K. SILVENTIONEN i A.H. GAUTHIER, "Parenthood and psychological well-being in Finland: Does public policy make a difference?", Journal of Comparative Family Studies, 32(1), 2001., 61-75.

63/ K. W. SCHAIE, i S.L. WILLIS, Adult development and aging, 4th edition. New York: Harper Collins, College Publishers, 1996.

64/ R. SCHOEN, Z.J. KIM, C.A. NATHANSON, J. FIELDS i N.M. ASTONE, "Why do Americans want children?", Population and Development Review, 23, 1997. 333-358.

65/ L. STANCA, "Suffer the little children: Measuring the effect of parenthood on well-being worldwide" Milan: University of Milan Bicocca. Department of Economics, 2009, preuzeto 22.10.2019. s https://boa.unimib.it/retrieve/ handle/10281/23061/29614/Suffer_the_Little_Children_Measuring_the_ effects_of_Parenthood_on_well-being_Worldwide.pdf

66/ L. STANCA, "Suffer the little children: Measuring the effects of parenthood on well-being worldwide", Journal of Economic Behavior \& Organization, 81(3), 2012., 742-750. 
67/ K. STANLEY, L. EDWARDS i B. HATCH, The family report 2003: Choosing happiness?, London: Institute for Public Policy Research, 2003., preuzeto 20.10.2019. s https://www.ippr.org/files/images/media/files/publication/2011/05/2003\%20Parents\%20_rochure\%20FINAL1_1308.pdf

68/ B. G. TABACHNICK i L.S. FIDELL, Using Multivariate Statistics (5th ed.), New York: Allyn and Bacon, 2007.

69/ H. TILIOUINE, R.A. CUMMINS, i M. DAVERN, "Measuring wellbeing in developing countries: the case of Algeria", Social Indicators Research, 75(1), 2006., 1-30.

70/ L. TOULEMON, "Very few couples remain voluntarily childless", Population. English selection, 8, 1996., 1-27.

71/ D. UMBERSON, i W. R. GOVE, "Parenthood and psychological well-being: Theory, measurement, and stage in the family life course", Journal of family issues, 10(4), 1989., 440-462.

72/ D. UMBERSON, T. PUDROVSKA, i C .RECZEK, "Parenthood, childlessness, and well-being: A life course perspective", Journal of Marriage and Family, 72(3), 2010., 612-629.

73/ R. VEENHOVEN, "How do we assess how happy we are? Tenets, implications and tenability of three theories", Happiness, economics and politics, 2009., 45-69.

74/ M. WAGNER, Y. SCHUTZE i F.R. LANG, "Social relationships in old age" U P. B. Baltes i K. U. Mayer (ur.), The Berlin Aging Study. Aging from 70 to 10, New York: Cambridge University Press, 1999., 282-301.

75/ M. P. WHITE i P. DOLAN, "Accounting for the richness of daily activities", Psychological Science, 20, 2009., 1000-1008.

76/ E. WILLS, "Spirituality and Subjective Well-Being: Evidences for a New Domain in the Personal Well-Being Index", Journal of Happiness Studies, 10(1), 2009., 49-69.

77/ WORLD VALUES SURVEY, 2007., preuzeto 30.10.2019. s http://www.worldvaluessurvey.org/wvs.jsp

78/ Z. ZHANG i M.D. HAYWARD, "Childlessness and the psychological well-being of older persons", Journals of Gerontology Series B-Psychological Sciences and Social Sciences, 56(5), 2001., 311-320. 


\section{SAŽETAK}

\section{ODNOS RODITELJSTVA S INDIKATORIMA DOBROBITI}

Cilj ovoga istraživanja bio je istražiti razlike u dobrobiti pojedinaca s obzirom na njihov roditeljski status. Nekonzistentni nalazi u dosadašnjim istraživanjima, ukazuju na potrebu za daljnjim istraživanjem razlika u indikatorima dobrobiti između osoba s i bez djece. Stoga se ovim istraživanjem, nastojalo utvrditi navedene razlike, koristeći pritom više indikatora dobrobiti, a s obzirom na dob i spol sudionika. U konačnici, zanimalo nas je ustvrditi možemo li i u kojoj mjeri zadovoljstvo životom kod osoba s djecom, u odnosu na one bez djece, objasniti socio-demografskim karakteristikama i zadovoljstvom specifičnim domenama života. Istraživanje je provedeno online u sklopu Hrvatskog longitudinalnog istraživanja dobrobiti (CRO-WELL), a korišteni su podaci iz drugog vala. Uzorak osoba s djecom ( $N=1294)$ bio je statistički starije dobi, više ih je bilo u braku/vezi, zaposleno i s nižima primanjima po članu obitelji u odnosu na uzorak osoba bez djece ( $N=1458$ ). U oba poduzorka bila je veća zastupljenost žena, a nisu se razlikovali po stupnju obrazovanja. Rezultati su pokazali da osobe s djecom izražavaju više zadovoljstvo životom, sreću i procvat te su doživjele manje negativnih emocija u odnosu na osobe bez djece. U pogledu zadovoljstva specifičnim aspektima života, osobe $s$ djecom su manje zadovoljne postignućem, pripadnošću zajednici, slobodnim vremenom i fizičkim izgledom, a više s obitelji, poslom i ljubavnim životom u odnosu na osobe bez djece. Spol i dob sudionika ostvaruje značajan interakcijski efekt $s$ roditeljstvom na zadovoljstvo pojedinim životnim domenama. Naknadne analize pokazale su da su mlađi roditelji najmanje zadovoljni slobodnim vremenom, ali su zadovoljniji pripadnošću zajednici u odnosu na starije roditelje, dok su pripadnošću zajednici najmanje zadovoljne starije osobe bez djece. Muškarci bez djece su najmanje od svih ostalih grupa zadovoljni ljubavnim životom, a manje su zadovoljni pripadnošću zajednici u odnosu na žene. Očevi su, u odnosu na ostale grupe, zadovoljniji fizičkim izgledom, dok su žene bez djece zadovoljnije prijateljima u odnosu na muškarce. Provedene regresijske analize, pokazale su značajan i sličan doprinos uvrštenih prediktora općem zadovoljstvu životom i kod osoba s djecom i kod osoba bez djece. Doprinos sociodemografskih karakteristika u prvom koraku analize objasnio je tek malen dio varijance zadovoljstva životom ( $7 \%$ - 10\%), no uvođenjem zadovoljstva specifičnim aspektima života objašnjeno je ukupno $62 \%$ varijance zadovoljstva životom na uzorku osoba s djecom i 61\% na uzorku osoba bez djece. U oba uzorka, viša razina zadovoljstva životom mogla se predvidjeti višim razinama zadovoljstva životnim standardom, postignućem, sigurnošću i ljubavnim životom. U uzorku 
osoba s djecom, značajnim prediktorima pokazali su se i zadovoljstvo sigurnošću u budućnost i poslom, a u uzorku osoba bez djece zadovoljstvo pripadnošću zajednici.

Ključne riječi: roditeljstvo; dobrobit; zadovoljstvo životom; sreća; PWI.

\section{SUMMARY}

\section{THE RELATIONSHIP OF PARENTING TO INDICATORS OF WELL-BEING}

This study aimed to compare well-being of parents and childless individuals. Available literature shows inconsistency in results, indicating a need to further investigate possible differences between people who do or do not have children. This research aimed to explore these differences, by using various indicators of well-being, considering age and sex of participants. Finally, we were interested to explore the amount of variance of life satisfaction, can be explained by socio-demographic characteristics and satisfaction with specific life domains, and are there differences between participants who do or do not have children. For the purpose of this study, we used online gathered data from the second wave of Croatian longitudinal study on well-being. The sample of participants who had children $(\mathrm{N}=1294)$ was older, more often in relationship or marriage and employed but with lower income per family member when compared to sample of childless participants $(\mathrm{N}=1458)$. In both samples, majority were women and participants did not differ regarding education level. Results showed that participants with children were more satisfied with life, happier and had flourished more, but experienced less negative affect compared to their counterparts. Gender and age showed significant interaction effect with parenthood on satisfaction with specific life domains. Post hoc analyses revealed younger parents as least satisfied with free time, but more satisfied with community connectedness compared to older parents, while lowest satisfaction with community connectedness was in the group of older childless participants. Men without children were least satisfied with love life compared to all other groups, and less satisfied with community connectedness compared to women. Fathers were more satisfied with physical appearance compared to all other groups, while women without children were more satisfied with friends compared to men. Regression analyses revealed that various predictors explain life satisfaction significantly and in similar amount for both groups of participants. Results of regression analyses, using socio-demographic characteristics and satisfaction with specific domains as pre- 
dictors, showed that it is possible to explain $62 \%$ of variance in group of parents and $61 \%$ in group of childless participants. In both groups, those who were more satisfied with life standard, achievement, safety and love life, were also more satisfied with life in general. In the group of parents, above already mentioned, life satisfaction was also predicted by satisfaction with future security and work, while in the childless sample satisfaction with community connectedness.

Key words: parenthood; well-being; life satisfaction; happiness; PWI. 